\title{
Effects of rumen-protected methionine on lactation performance and physiological variables during a heat stress challenge in lactating Holstein cows
}

\author{
R. T. Pate, ${ }^{1} \odot$ D. Luchini,${ }^{2}$ M. R. Murphy, ${ }^{1}$ and F. C. Cardoso ${ }^{1 *}{ }^{1}$ \\ ${ }^{1}$ Department of Animal Sciences, University of Illinois, Urbana 61801 \\ ${ }^{2}$ Adisseo, Alpharetta, GA 30022
}

\begin{abstract}
Milk yield, content, and composition are altered by heat stress. Thirty-two multiparous, lactating Holstein cows [balanced by days in milk (mean \pm standard deviation; $184 \pm 59)$; body surface area $\left(5.84 \pm 0.34 \mathrm{~m}^{2}\right)$ ] were randomly assigned to 1 of 2 dietary treatments [total mixed ration with rumen-protected Met (RPM; Smartamine M; Adisseo Inc., Antony, France; 1.05 g of $\mathrm{RPM} / \mathrm{kg}$ of dry matter intake) or total mixed ration without RPM (CON)], and within each dietary treatment group cows were randomly assigned to 1 of 2 environmental treatment groups in a split-plot crossover design. The study was divided into 2 periods with 2 phases per period. In phase $1(9 \mathrm{~d})$, all cows were in thermoneutral conditions and fed ad libitum. In phase $2(9 \mathrm{~d})$, group $1(\mathrm{n}=16)$ was exposed to a heat stress challenge (HSC) using electric heat blankets. Group 2 $(\mathrm{n}=16)$ remained in thermoneutral conditions but was pair-fed (PFTN) to HSC counterparts. After a 21-d washout period, the study was repeated (period 2) and the environmental treatments were inverted relative to treatments from phase 2 of period 1 , whereas dietary treatments (RPM or CON) remained the same for each cow. Cows were milked $3 \times$ per day and samples were taken on d 1, 5, and 9 of each phase. Vaginal temperature was measured every $10 \mathrm{~min}$, rectal temperature and skin temperature were measured $3 \times$ per day, and respiration rate and heart rate were recorded once per day. Cow activity was measured using an accelerometer. Paired difference values were calculated for each cow for each period based on the difference between phase 1 baseline means and phase 2 values for each variable. Cows in HSC had a greater increase in vaginal temper-
\end{abstract}

Received July 22, 2019.

Accepted November 14, 2019.

*Corresponding author: cardoso2@illinois.edu ature and respiration rate $\left(+0.2^{\circ} \mathrm{C}\right.$ and +13.7 breaths/ min, respectively) compared with cows in PFTN $\left(0.0^{\circ} \mathrm{C}\right.$ and -1.6 breaths/min, respectively). Cows in PFTN had a greater decrease in dry matter intake and milk yield ( -3.9 and $-2.6 \mathrm{~kg} / \mathrm{d}$, respectively) compared with cows in HSC ( -3.2 and $-0.9 \mathrm{~kg} / \mathrm{d}$, respectively). Cows in $\mathrm{CON}$ had a greater decrease in milk protein concentration for PFTN ( -0.10 percentage units) and HSC ( -0.06 percentage units) compared with cows in RPM for PFTN (0.00 percentage units) and HSC ( -0.02 percentage units). Cows in CON for HSC had greater decrease in milk fat concentration compared with cows in RPM for HSC $(-0.10$ and +0.12 percentage units, respectively). In conclusion, HSC altered physiological and production parameters of cows. Additionally, RPM helped maintain milk protein and fat concentration during HSC, whereas dry matter intake, milk yield, and feed efficiencies were not affected by RPM.

Key words: heat stress, methionine, pair-fed, behavior

\section{INTRODUCTION}

Heat stress (HS) occurs in dairy cattle when a negative balance is present between the amount of heat energy an animal produces and the amount transferred from the animal to its surrounding environment (NRC, 2001). An estimated $\$ 2.4$ billion is lost annually in livestock production due to effects of HS. In particular, the dairy industry contributes roughly $\$ 900$ million to this total (St-Pierre et al., 2003). These economic losses within the dairy industry are mostly attributed to decreased milk production, adverse effects on milk composition, decreased reproductive performance, and increased culling rate (St-Pierre et al., 2003). Many heat abatement practices have been implemented on dairy farms. Some of these practices include increasing shaded areas, increasing air velocity by use of fans, and the use of water-soaker lines to increase evaporative heat loss. Although these management practices are implemented, HS still causes significant economic issues for dairy producers on a national and global scale. 
Dairy cattle use multiple acute physiological adaptions to regulate core body temperature and maintain thermoneutrality. The major acute mechanisms for heat loss are evaporative heat loss through perspiration and elevated respiration rate (Lemerle and Goddard, 1986; Kadzere et al., 2002), increased water intake (Silanikove et al., 1998; Bernabucci et al., 2010), and decreased DMI (Cowley et al., 2015; Gao et al., 2017). Decreased DMI is likely an inherent response by the cow to reduce heat increment incurred via metabolism of feed and subsequent milk production (Cowley et al., 2015; Collier et al., 2017). This is supported by the fact that Maust et al. (1972) reported a negative correlation between feed intake and rectal temperature in pigs. Historically, decrease in DMI has been assumed to be the primary driver of decreased milk yield during HS (Beede and Collier, 1986; West, 1999). However, recent work has reported that the decrease in DMI only accounts for approximately 35 to $50 \%$ of the decrease in milk yield and that other more chronic physiological and metabolic alterations also play a role in explaining it (Wheelock et al., 2010; Baumgard et al., 2011). Not only is overall milk yield decreased during HS, but milk composition is also altered, specifically milk protein concentration. Previous research has reported decreases in milk protein and milk casein concentration when cows were subject to environments with an elevated temperature-humidity index (THI; Nardone et al., 1997; Cowley et al., 2015; Gao et al., 2017). These alterations in milk composition seem to be due to factors beyond a decrease in DMI, and are likely caused by reduced delivery of protein precursors to the mammary gland, and increased utilization of AA for other biochemical processes, such as gluconeogenesis, and acute phase protein and heat shock protein synthesis (Bernabucci and Calamari, 1998; Collier et al., 2008; Baumgard and Rhoads, 2013; Ríus, 2019).

Feeding diets balanced for proper AA proportions in MP using rumen-protected AA aids lactation performance and milk protein and fat concentration, while also improving responses to stressful conditions when DMI often decreases (NRC, 2001; Osorio et al., 2013; Zhou et al., 2016; Batistel et al., 2017). Specifically, improved lactation performance and reduced inflammatory responses have been reported when rumenprotected Met (RPM) was added to the diet of cows during the transition period (Osorio et al., 2013; Zhou et al., 2016; Batistel et al., 2017). Although RPM inclusion in the diets of dairy cattle in other stress conditions (e.g., parturition) have been extensively studied, minimal research evaluating RPM effects during HS has been performed. Therefore, the objectives of this study were to evaluate the effects of a commercially available RPM source (Smartamine M; Adisseo Inc., Antony,
Table 1. Ingredient composition of the lactation diet fed to all cows during the experimental period

\begin{tabular}{|c|c|}
\hline Ingredient & $\%$ of DM \\
\hline Corn silage $^{1}$ & 40.88 \\
\hline Dry ground corn grain & 17.69 \\
\hline Alfalfa silage & 12.28 \\
\hline Corn gluten feed pellets & 8.42 \\
\hline Alfalfa hay & 6.32 \\
\hline Mineral and vitamin $\operatorname{mix}^{2}$ & 3.62 \\
\hline Soybean meal RUP source ${ }^{3}$ & 3.36 \\
\hline Molasses & 3.30 \\
\hline Canola meal & 1.68 \\
\hline Rumen inert fat ${ }^{4}$ & 1.4 \\
\hline Blood meal ${ }^{5}$ & 0.42 \\
\hline Rumen-protected lysine ${ }^{6}$ & 0.42 \\
\hline Urea $46 \%$ & 0.21 \\
\hline
\end{tabular}

${ }^{1}$ All treatments fed at $34.4 \%$ corn silage DM.

${ }^{2}$ Mineral and vitamin mix was formulated to contain $12.51 \% \mathrm{Ca}$, $14.06 \% \mathrm{Na}, 9.60 \% \mathrm{Cl}, 3.18 \% \mathrm{Mg}, 6.48 \% \mathrm{~K}, 0.19 \% \mathrm{~S}, 26.93 \mathrm{mg} / \mathrm{kg} \mathrm{Co}$, $301.01 \mathrm{mg} / \mathrm{kg} \mathrm{Cu}, 40.22 \mathrm{mg} / \mathrm{kg} \mathrm{I}, 678.25 \mathrm{mg} / \mathrm{kg} \mathrm{Fe}, 1,519.35 \mathrm{mg} / \mathrm{kg}$ $\mathrm{Mn}, 8.62 \mathrm{mg} / \mathrm{kg} \mathrm{Se}, 4.47 \mathrm{mg} / \mathrm{kg}$ organic Se, 1,621.05 mg/kg Zn, 43.34 $\mathrm{kIU} / \mathrm{kg}$ vitamin $\mathrm{A}, 10.89 \mathrm{kIU} / \mathrm{kg}$ vitamin $\mathrm{D}_{3}, 466.41 \mathrm{IU} / \mathrm{kg}$ vitamin $\mathrm{E}, 4.23 \mathrm{mg} / \mathrm{kg}$ biotin, $46.65 \mathrm{mg} / \mathrm{kg}$ thiamine, and $0.35 \mathrm{~g} / \mathrm{kg}$ monensin (Rumensin, Elanco, Greenfield, IN).

${ }^{3}$ SoyPlus (Dairy Nutrition Plus, Ralston, IA).

${ }^{4}$ Energy Booster 100 (Milk Specialties Global, Eden Prairie, MN).

${ }^{5}$ ProVAAl AADvantage (Perdue AgriBusiness, Salisbury, MD).

${ }^{6}$ Ajipro-L Generation 3 (Ajinomoto Heartland Inc., Chicago, IL).

France) fed at $1.05 \mathrm{~g}$ of RPM/kg of DMI on lactation performance and physiological responses of lactating, multiparous Holstein cows during a HS challenge.

\section{MATERIALS AND METHODS}

\section{Animal Care and Housing}

All experimental procedures were approved by the University of Illinois (Urbana-Champaign) Institutional Animal Care and Use Committee (no. 18156). The experimental period occurred from September 2018 to December 2018. Diet (TMR) was formulated using AMTS.Cattle.Pro version 4.7 (2017, AMTS LLC, Groton, NY; Table 1) based on cows at 180 DIM, 750 $\mathrm{kg}$ of $\mathrm{BW}$, producing $40 \mathrm{~kg}$ of milk/d with a target $3.7 \%$ milk fat and $3.2 \%$ milk protein, and a predicted DMI of $25.5 \mathrm{~kg} / \mathrm{d}$. Cows were housed in a tiestall barn and had constant access to water.

\section{Experimental Design and HS Procedure}

A total of 32 multiparous lactating Holstein cows [balanced by DIM $($ mean $\pm \mathrm{SD})=184 \pm 59 \mathrm{~d}$; lactation number $=2.8 \pm 1.1$; body surface area $(0.14 \times$ $\mathrm{BW}^{0.57}$; Berman, 2003) $\left.=5.84 \pm 0.34 \mathrm{~m}^{2}\right]$ were randomly assigned to 1 of 2 dietary treatments [TMR with rumen-protected Met (RPM treatment; Smartamine 
$\mathrm{M}$; Adisseo Inc., Antony, France; $1.05 \mathrm{~g}$ of RPM/kg of DMI) or TMR without RPM (control treatment; CON)], and within each dietary treatment group cows were randomly assigned to 1 of 2 environmental treatment groups in a split-plot crossover design (Table 2). The study was divided into 2 periods (period 1 and 2) with 2 identical experimental phases (phase 1 and 2) within each period. Before each period, an adaption phase $(7 \mathrm{~d})$ occurred in which cows were fed their respective dietary treatment and no sample collection occurred. During phase 1 (baseline phase; $9 \mathrm{~d}$ ), all cows were in thermoneutral conditions $\{\mathbf{T N} ; 16.0 \pm$ $2.5^{\circ} \mathrm{C} ; 71.4 \pm 7.5 \%$ relative humidity $(\mathbf{R H}) ; \mathrm{THI}=$ $60 \pm 3 ; \mathrm{THI}=\mathrm{T}^{\circ} \mathrm{C}_{\mathrm{dry}}$ bulb $-[0.55-(0.55 \times \mathrm{RH} / 100)]$ $\times\left(\mathrm{T}^{\circ} \mathrm{C}_{\text {dry bulb }}-58\right)$; Buffington et al., 1981$\}$ and fed ad libitum. Ambient temperature and humidity were recorded in the experimental barn using a data logger (HOBO U23 v2 External Temperature/Relative Humidity Data Logger, Onset Computer Corp., Bourne, MA) every 15 min. During phase 2 (trial phase; 9 d), group $1(\mathrm{n}=16)$ was exposed to a heat stress challenge (HSC) using methods similar to Al-Qaisi et al. (2019), where cows were fitted with an electric heat blanket $($ EHB $; 1.87 \times 1.59 \mathrm{~m} ; 100 \%$ nylon with polyurethane coating; weight $=7.7 \mathrm{~kg}$ ) consisting of 12 infrared heating pads as a heat source that generated a temperature of $36^{\circ} \mathrm{C}$, according to the manufacturer (Thermotex Therapy Systems Ltd., Calgary, AB, Canada). Electric heat blankets remained on group 1 cows for the entire duration of phase 2. Meanwhile, group $2(\mathrm{n}=$ 16) remained in $\mathrm{TN}$ conditions $\left(16.8 \pm 2.6^{\circ} \mathrm{C} ; 66.8 \pm\right.$ $8.1 \% \mathrm{RH}$; THI $=61 \pm 4$ ) but was pair-fed $($ PFTN $)$ to their HSC counterparts. To calculate the amount of feed offered to the PFTN cows based on the intake of the HSC cows, the trial (sampling and feed restriction) started and ran $1 \mathrm{~d}$ behind HS cows for the PFTN cows as previously described (Wheelock et al., 2010; Gao et al., 2017). For pair-feeding calculations, the ad libitum daily DMI was averaged for each cow for phase 1 and used as a baseline. For each cow in HSC, the decrease in DMI during phase 2 was calculated as the percentage reduction in DMI relative to the phase 1 baseline DMI for each day of HSC, as shown below:

daily individual percentage change in $\mathrm{DMI}=$

[(daily individual phase 2 DMI - average individual

phase $1 \mathrm{DMI}$ )/average individual phase $1 \mathrm{DMI}] \times 100$.

The percentage of DMI reduction was averaged for all of the cows in HSC per day of phase 2 and applied individually to the baseline DMI of each cow in PFTN, as shown below: daily individual phase 2 PFTN TMR allocation $=$ average individual phase 1 DMI - (average individual phase $1 \mathrm{DMI} \times$ average HSC daily percentage change in DMI).

The treatments during phase 2 were HSC and RPM (HSC-M), HS and CON (HSC-C), PFTN and RPM (PF-M), and PFTN and CON (PF-C). After a 14-d washout period and 7-d adaption period in TN conditions, the study was repeated (period 2) and the environmental treatments were inverted relative to treatments from phase 2 of period 1 , while the dietary treatments (RPM or CON) remained the same as in period 1 for each cow. The same TMR was fed to all cows throughout the experimental period. During phase 1, all cows were fed once daily at $1300 \mathrm{~h}$. During phase 2 , HSC cows were fed once daily at $1300 \mathrm{~h}$, whereas for PFTN cows the calculated TMR allocation was divided in 2 and offered at 1300 and $2200 \mathrm{~h}$ to minimize the potential effect of slug-feeding. The daily RPM allocation (1.05 g of RPM $/ \mathrm{kg}$ of DMI) for cows in RPM was mixed with $300 \mathrm{~g}$ of molasses and top dressed onto the TMR immediately after feeding. Cows in CON were administered a top dress consisting of $300 \mathrm{~g}$ of molasses only onto the TMR immediately after feeding. The dosage rate of $1.05 \mathrm{~g}$ of $\mathrm{RPM} / \mathrm{kg}$ of DMI allowed for proper AA balancing of the diet based on relevant literature (NRC, 2001; Schwab et al., 2009; Van Amburgh et al., 2009; Schwab, 2012). Based on AMTS.Cattle.Pro version 4.7 (2017, AMTS, LLC, Groton, NY) predictions, cows in RPM received $2.72 \mathrm{~kg}$ of MP per day, and $2.57 \%$ of MP as Met, $7.01 \%$ of MP as Lys, and $2.47 \%$ of MP as His with a Lys:Met of 2.73 and a His:Met of 0.96; whereas cows in CON received $2.71 \mathrm{~kg}$ of MP per day, and $2.03 \%$ of MP as Met, $7.05 \%$ of MP as Lys, and $2.49 \%$ of MP as His with a Lys:Met of 3.47 and a His: Met of 1.22 .

\section{Data Collection and Sampling Procedure}

Samples of TMR were collected $3 \times$ per week and analyzed for DM (AOAC International, 1995a) by drying in a forced-air oven at $110^{\circ} \mathrm{C}$ for $24 \mathrm{~h}$. Diet composition was adjusted weekly for DM content changes of ingredients. The daily TMR offered and refused was logged from each cow to determine intake based on DM analyses conducted $3 \times$ per week. Collection of TMR samples was done weekly (4 per period) and stored at $-20^{\circ} \mathrm{C}$ until analyzed. Composite samples for each period $(\mathrm{n}=$ 2) were analyzed for contents of DM, CP, ADF, NDF, NDF digestible $(30 \mathrm{~h})$, undigestible NDF (30 h), lignin, NFC, NSC, starch, sugar, fat, ash, $\mathrm{NE}_{\mathrm{L}}, \mathrm{Ca}, \mathrm{P}, \mathrm{Mg}$, 


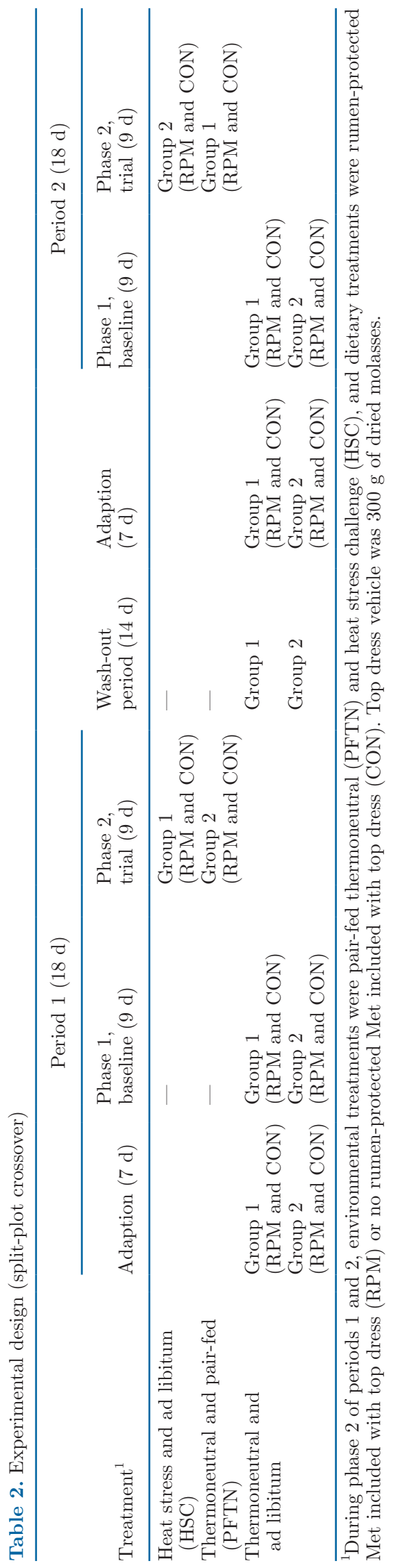

Table 3. Mean chemical composition and associated SD for diets fed to all cows throughout the experimental period

\begin{tabular}{|c|c|c|}
\hline Item & Mean $^{1}$ & SD \\
\hline $\mathrm{DM}, \%$ & 46.8 & 2.8 \\
\hline $\mathrm{CP}, \%$ of $\mathrm{DM}$ & 16.0 & 0.5 \\
\hline Total-tract undigested protein, ${ }^{2} \%$ of DM & 3.8 & 0.2 \\
\hline Total-tract undigested protein. ${ }^{2} \%$ of $\mathrm{CP}$ & 23.9 & 1.3 \\
\hline $\mathrm{ADF}, \%$ of $\mathrm{DM}$ & 20.0 & 0.8 \\
\hline $\mathrm{NDF}, \%$ of $\mathrm{DM}$ & 29.5 & 1.5 \\
\hline NDF digestibility $(30 \mathrm{~h}), \%$ of DM & 16.2 & 0.8 \\
\hline Undigestible NDF (30 h), \% of DM & 13.3 & 0.7 \\
\hline Lignin, $\%$ of DM & 3.5 & 0.1 \\
\hline NFC, $\%$ of DM & 43.2 & 1.4 \\
\hline NSC, $\%$ of DM & 32.1 & 1.7 \\
\hline Starch, \% of DM & 28.3 & 1.7 \\
\hline Sugar, $\%$ of DM & 3.8 & 0.2 \\
\hline Crude fat, $\%$ of DM & 4.5 & 0.1 \\
\hline Ash, \% of DM & 8.16 & 0.38 \\
\hline $\mathrm{NE}_{\mathrm{L}},{ }^{3} \mathrm{Mcal} / \mathrm{kg}$ of $\mathrm{DM}$ & 1.68 & 0.02 \\
\hline $\mathrm{Ca}, \%$ of $\mathrm{DM}$ & 1.07 & 0.11 \\
\hline P. $\%$ of DM & 0.38 & 0.02 \\
\hline $\mathrm{Mg}, \%$ of $\mathrm{DM}$ & 0.32 & 0.01 \\
\hline $\mathrm{K}, \%$ of $\mathrm{DM}$ & 1.84 & 0.06 \\
\hline $\mathrm{Na}, \%$ of $\mathrm{DM}$ & 0.57 & 0.02 \\
\hline $\mathrm{S}, \%$ of $\mathrm{DM}$ & 0.22 & 0.01 \\
\hline $\mathrm{Cl}, \%$ of $\mathrm{DM}$ & 0.72 & 0.05 \\
\hline $\mathrm{Fe}, \mathrm{mg} / \mathrm{kg}$ & 251 & 28 \\
\hline $\mathrm{Zn}, \mathrm{mg} / \mathrm{kg}$ & 109 & 8 \\
\hline $\mathrm{Cu}, \mathrm{mg} / \mathrm{kg}$ & 15 & 1 \\
\hline $\mathrm{Mn}, \mathrm{mg} / \mathrm{kg}$ & 90 & 4 \\
\hline DCAD ${ }^{4} \mathrm{mEq} / 100 \mathrm{~g}$ of $\mathrm{DM}$ & 37.9 & 2.2 \\
\hline
\end{tabular}

${ }^{1}$ Mean diet composition of phases 1 and 2 from periods 1 and $2(\mathrm{n}=$ 4). Samples were taken before top dress administration.

${ }^{2}$ Intestinal undigested residue, recovered on a $1.5-\mu \mathrm{m}$ filter (Ross et al., 2013).

${ }^{3} \mathrm{NRC}(2001)$.

${ }^{4} \mathrm{DCAD}=(\mathrm{Na}+\mathrm{K})-(\mathrm{Cl}+\mathrm{S})$.

$\mathrm{K}, \mathrm{Na}, \mathrm{S}, \mathrm{Cl}, \mathrm{Fe}, \mathrm{Zn}, \mathrm{Cu}, \mathrm{Mn}$, and DCAD using wet chemistry methods (Cumberland Valley Analytical Services, Waynesboro, PA; Table 3). Values for $\mathrm{NE}_{\mathrm{L}}$ were provided by the laboratory and were calculated according to NRC (2001). Additionally, composite TMR samples for each period were analyzed for contents of total-tract undigested protein using ruminal and intestinal digestibility of protein assays as described by Ross et al. (2013; Cumberland Valley Analytical Services, Waynesboro, PA; Table 3). Physical characterization of the TMR was performed weekly using the Penn State Particle Separator (Kononoff et al., 2003).

Cows were milked $3 \times$ per day at 0400,1200 , and 1930 h. During phase 2, EHB remained fastened to the cows in HSC at all times; however, the electrical source was removed to allow cows to be taken to the parlor for milking (approximately $1 \mathrm{~h}$ per milking). Milk weights were recorded at each milking, and milk samples were taken on d 1, 5, and 9 of each phase during each period. A preservative (800 Broad Spectrum Microtabs II, D\&F Control Systems Inc., San Ramon, CA) was added to all milk samples. Preserved samples were stored at $8^{\circ} \mathrm{C}$ 
in a refrigerator, composited in proportion to milk yield at each milking, and sent to a commercial laboratory (Dairy One, Ithaca, NY). Milk samples were analyzed for fat, true protein, MUN, lactose, TS, total casein, and for SCC using mid-infrared procedures (AOAC International, 1995b). Additionally, milk samples were sent to a commercial laboratory (ADM Laboratories, Clovis, NM) and analyzed for concentration of de novo fatty acids (FA), preformed FA, and mixed FA using mid-infrared procedures as described by Wojciechowski and Barbano (2016).

Vaginal temperature was measured using HighResolution Thermochron iButton Devices (model DS1921H, Maxim Integrated Products Inc., San Jose, CA) fastened to drug-free, controlled internal drug release devices (Eazi-Breed CIDR Cattle Insert, Zoetis Services LLC, Parsippany, NJ) placed inside the vaginal cavity. Vaginal temperature was recorded every 10 min throughout phase 1 and 2 of each period. Rectal temperature and skin temperature were measured $3 \times$ per day when cows returned from each milking at approximately 0500,1300 , and $2030 \mathrm{~h}$. Rectal temperature was measured using a GLA M700 Thermometer (GLA Agricultural Electronics, San Luis Obispo, CA). Skin temperature was measured on the neck using an infrared thermometer (model MS6520H 10:1 Infrared Thermometer, Commercial Electric, Cleveland, $\mathrm{OH}$ ). Health evaluations (general appearance, fecal score, respiration rate, and heart rate) were conducted $1 \times$ per day during phase 1 and 2 of each period when cows returned from milking at approximately $1300 \mathrm{~h}$. Visual assessments were used to monitor general appearance and fecal score. General appearance was scored using a method similar to Krause et al. (2009): $4=$ bright and alert; $3=$ depressed; $2=$ reluctant to rise; $1=$ down cow, will not get up. Fecal scores were assigned on a 1 to 4 scale similar to Krause et al. (2009): 1 = runny: liquid consistency, splatters on impact, spreads readily; $2=$ loose: may pile slightly and spreads and splatters moderately on impact and setting; $3=$ soft: piles up but spreads slightly on impact and settling; $4=$ dry: hard, dry appearance, original form not distorted on impact and settling. Respiration rate was recorded by visual observation for $15 \mathrm{~s}$, and heart rate was measured via palpation of the femoral artery for $15 \mathrm{~s}$. Evaluations of BW (digital scale, model CW-11, Ohaus, Newark, NJ) and BCS [assigned in quarter-unit increments for each cow (Ferguson et al., 1994) by more than one person independently at each time of scoring; the average score was used for statistical analysis] were performed on $\mathrm{d}$ $-3,-2$, and -1 before phase 1 ; on $\mathrm{d} 7,8$, and 9 of phase 1; and on d 7, 8 , and 9 of phase 2 for each period as described in Pate and Cardoso (2018).
Cow activity was measured using an accelerometer (HOBO Pendant G Accelerometer Data Logger, Onset Computer Corp., Bourne, MA) attached laterally to the distal right hind leg using veterinary wrap. The activity monitor measured lying and standing behavior, similar to methods validated by Ledgerwood et al. (2010). The activity logger recorded data in 5-min intervals. Data collected was used to calculate standing time, standing bouts (per $24 \mathrm{~h}$ ), and duration of each standing bout, as well as lying time, lying bouts (per $24 \mathrm{~h}$ ), and duration of each lying bout.

\section{Statistical Analyses}

Data collected from period 1 and 2 were analyzed using SAS (v. 9.4, SAS Institute Inc., Cary, NC). The study used was a crossover design with 2 periods, 2 dietary treatments, 2 environmental treatments (during phase 2), and 2 groups of cows (Table 2). Observations during phase 1 (baseline phase) of each period were averaged and used as baseline to calculate paired difference values for each cow based on the difference between phase 1 baseline means and phase 2 (trial phase) values for each variable. The MIXED procedure of SAS was used for paired difference values with single measurements in each period. The model included sequence, environment, diet, environment $\times$ diet interaction, and period as fixed effects; and cow within sequence as a random effect using the following model:

$$
Y_{i j k l m}=\mu+S_{i j}+E_{k}+T_{l}+(E T)_{k l}+P_{n}+C_{i}+\varepsilon_{i j k l m},
$$

where $Y_{i j k l m}=$ the observations for dependent variables; $\mu=$ the overall mean; $S_{i j}=$ the fixed effect of the $i$ th cow in the $j$ th sequence; $E_{k}=$ the fixed effect of the $k$ th environment (TN or HSC); $T_{l}=$ the fixed effect of the lth diet (RPM or CON); $(E T)_{k l}=$ the interaction of environment and diet; $P_{n}=$ the fixed effect of the $n$th period; $C_{i}=$ the random effect of the $i$ th cow within sequence; and $\varepsilon_{i j k l m}=$ the random residual error.

The MIXED procedure of SAS was used for paired difference values of variables with multiple measurements within the same period, with day of phase 2 as the repeated effect. The model included sequence, environment, diet, environment $\times$ diet interaction, environment $\times$ day interaction, diet $\times$ day interaction, environment $\times$ diet $\times$ day interaction, and period as fixed effects; cow within sequence as a random effect; and day of phase 2 as the repeated effect using the following model:

$$
\begin{aligned}
Y_{i j k l m} & =\mu+S_{i j}+E_{k}+T_{l}+D_{m}+(E T)_{k l}+(E D)_{k m} \\
& +(T D)_{l m}+(E T D)_{k l m}+P_{n}+C_{i}+\varepsilon_{i j k l m n}
\end{aligned}
$$


where $Y_{i j k l m}=$ the observations for dependent variables; $\mu=$ the overall mean; $S_{i j}=$ the fixed effect of the $i$ th cow in the $j$ th sequence; $E_{k}=$ the fixed effect of the $k$ th environment (TN or HSC); $T_{l}=$ the fixed effect of the lth diet (RPM or CON); $D_{m}=$ the repeated measurement (day) effect; $(E T)_{k l}=$ the interaction of environment and diet; $(E D)_{k m}=$ the interaction of environment and day; $(T D)_{l m}=$ the interaction of diet and day; $(E T D)_{k l m}=$ the 3-way interaction of environment, diet, and day; $P_{n}=$ the fixed effect of the $n$th period; $C_{i}=$ the random effect of the $i$ th cow within sequence; and $\varepsilon_{i j k l m n}=$ the random residual error. The estimation method was REML and the degrees of freedom method was Kenward-Rogers (Littell, 2002). Variables were subjected to 5 covariance structures: compound symmetry, unstructured, autoregressive order 1, autoregressive heterogeneous order 1 , and Toeplitz. The covariance structure that yielded the lowest corrected Akaike information criterion was compound symmetry and was used in the model (Littell, 2002). Statistical significance was declared at $P \leq 0.05$ and trends at 0.05 $<P \leq 0.10$.

\section{RESULTS}

\section{Diet Composition}

Ingredient composition of the experimental TMR are in Table 1. Analyzed nutrient composition of the experimental TMR are in Table 3. The physical characteristics of the experimental TMR, based on the Penn State Particle Separator (Kononoff et al., 2003), were (mean $\pm \mathrm{SD}$ ): $3.2 \pm 0.9 \%$ on upper (19 $\mathrm{mm}$ pore size), $45.4 \pm 2.3 \%$ on middle ( $8 \mathrm{~mm}$ pore size), $12.2 \pm 2.6 \%$ on lower ( $4 \mathrm{~mm}$ pore size) sieves, and $39.2 \pm 3.2 \%$ in the pan.

\section{Physiological Parameters and Activity}

Body temperature indices and physiological measurement data are in Table 4 . Cows in HSC had a greater increase in vaginal temperature $\left(+0.2^{\circ} \mathrm{C} ; P<0.001\right)$ and rectal temperature $\left(+0.3^{\circ} \mathrm{C} ; P<0.001\right)$ compared with cows in PFTN $\left(0.0\right.$ and $0.0^{\circ} \mathrm{C}$, respectively). Cows in $\mathrm{HSC}$ had a greater increase in respiration rate $(+13.7$ breaths $/ \mathrm{min} ; P<0.001)$ and heart rate $(+2.0$ beats/ min; $P=0.001)$ compared with cows in PFTN $(-1.6$ breaths $/ \mathrm{min}$ and -0.8 beats $/ \mathrm{min}$, respectively). Cows in $\mathrm{HSC}$ tended to have a greater skin temperature than cows in PFTN $\left(+1.2\right.$ and $+0.9^{\circ} \mathrm{C}$, respectively; $P=$ 0.08). A tendency for an environment $x$ diet interaction was present for vaginal temperature $(P=0.07)$. A day effect was present for vaginal temperature $(P<0.001$; Figure 1A), skin temperature $(P<0.001)$, and heart

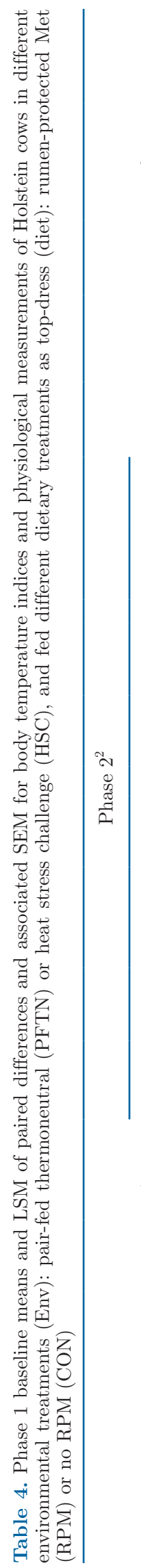

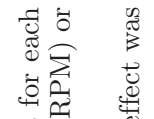

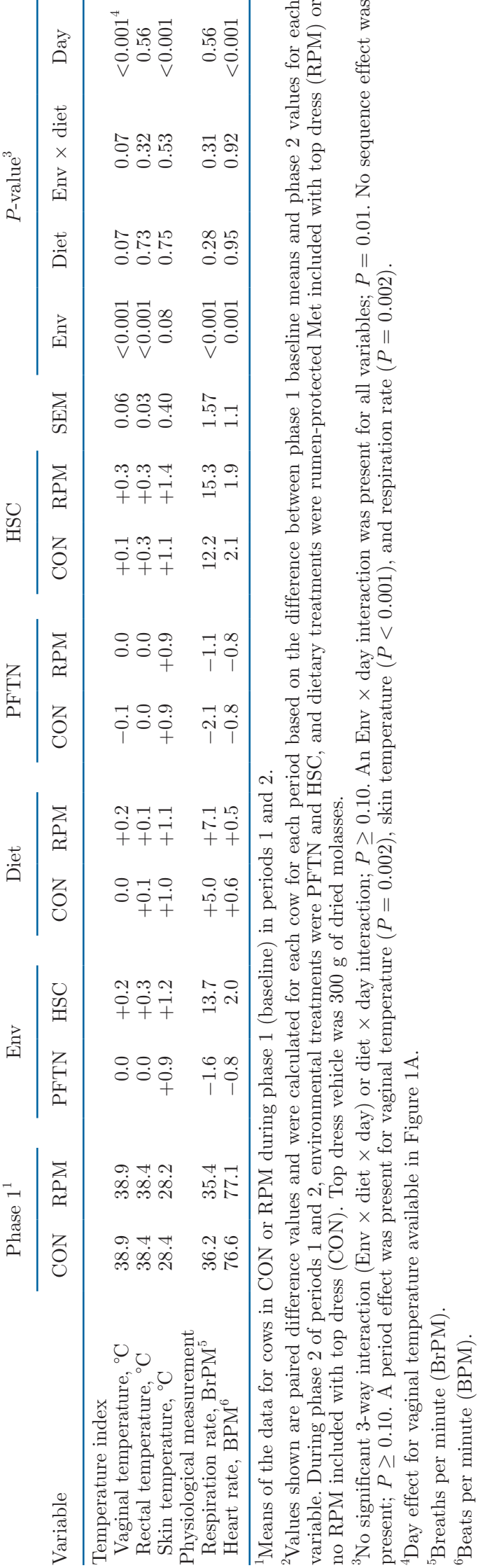



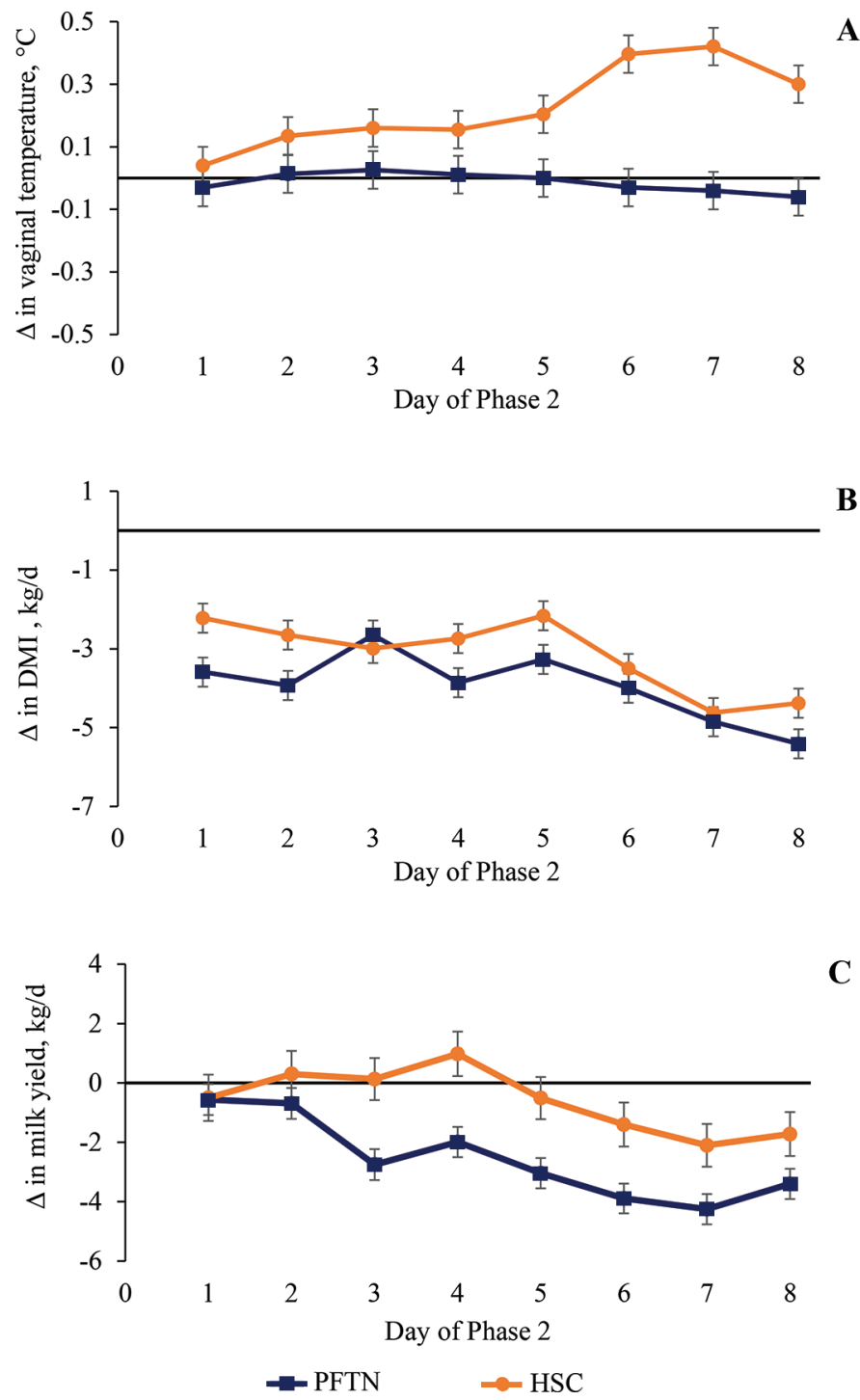

Figure 1. Least squares means of paired differences and associated SEM for vaginal temperature $\left({ }^{\circ} \mathrm{C} ; \mathrm{A}\right), \mathrm{DMI}(\mathrm{kg} / \mathrm{d} ; \mathrm{B})$, and milk yield $(\mathrm{kg} / \mathrm{d} ; \mathrm{C})$ for Holstein cows in different environmental treatments: pair-fed thermoneutral (PFTN, blue squares) or heat stress challenge (HSC, orange circles). Data were collected on each day of phase 2. Day effect: A, $P<0.001$; B, $P<0.001 ; \mathrm{C}, P<0.001$. Paired differences values were calculated for each cow for each period based on the difference between phase 1 baseline means (black horizontal line) and phase 2 values for each variable.

rate $(P<0.001)$. An environment $\times$ day interaction was present for all physiological parameters $(P=0.01)$.

Lying and standing behavior data are in Table 5 . Cows in HSC had a greater increase in standing bouts $(+0.5$ bouts $/ 24 \mathrm{~h} ; P<0.001)$ and standing time $(+82.1$ min; $P<0.001)$ compared with cows in PFTN $(-0.5$ bouts $/ 24 \mathrm{~h}$ and $+21.3 \mathrm{~min}$, respectively). Cows in HSC tended to have a greater increase in standing bout duration compared with cows in PFTN $(+9.1$ and +3.8 min, respectively; $P=0.07)$. Cows in HSC had a greater
A decrease in lying time $(-82.1 \mathrm{~min} ; P<0.001)$ and lying bout duration $(-5.1 \mathrm{~min} ; P<0.001)$ compared with cows in PFTN ( -21.3 and +1.5 min, respectively). An environment $x$ diet interaction was present for lying bouts $(P=0.004)$, lying time $(P=0.02)$, and standing time $(P=0.02)$. A day effect was present for all lying and standing behavior variables $(P<0.001)$. An environment $x$ day interaction was present for all lying and standing behavior variables $(P<0.001)$.

\section{DMI, BW, BCS, and Lactation Performance}

Performance data are in Table 6. Cows in PFTN had a greater decrease in DMI compared with cows in HSC $(-3.9$ and $-3.2 \mathrm{~kg} / \mathrm{d}$, respectively; $P=0.001)$. Cows in PFTN had a greater decrease in BW compared with cows in HSC ( -20 and $-8 \mathrm{~kg}$, respectively; $P=0.01$ ). Cows in PFTN had a greater decrease in milk yield $(-2.6 \mathrm{~kg} / \mathrm{d} ; P<0.001), 3.5 \%$ FCM yield $(-2.3 \mathrm{~kg} / \mathrm{d}$; $P=0.04)$, and ECM yield $(2.3 \mathrm{~kg} / \mathrm{d} ; P=0.04) \mathrm{com}-$ pared with cows in HSC $(-0.9,-1.0$, and $-1.1 \mathrm{~kg} / \mathrm{d}$, respectively). Cows in PFTN tended to have a greater decrease in milk fat yield $(-0.08 \mathrm{~kg} / \mathrm{d} ; P=0.09)$ and milk casein yield $(-0.06 \mathrm{~kg} / \mathrm{d} ; P=0.08)$ compared with cows in HSC $(-0.03$ and $-0.03 \mathrm{~kg} / \mathrm{d}$, respectively). Cows in PFTN had a greater decrease in milk lactose concentration $(-0.09$ percentage units; $P=0.004)$ and milk lactose yield $(-0.11 \mathrm{~kg} / \mathrm{d} ; P=0.04)$ compared with cows in HSC ( -0.03 percentage units and -0.05 $\mathrm{kg} / \mathrm{d}$, respectively). Cows in CON had greater $(P=$ $0.04)$ decrease in milk protein concentration for PFTN $(-0.10$ percentage units) and HSC ( -0.06 percentage units) compared with cows in RPM for PFTN (0.00 percentage units) and HSC ( -0.02 percentage units). Cows in CON tended to have a greater $(P=0.06)$ decrease in milk casein concentration for PFTN $(-0.10$ percentage units) and HSC ( -0.05 percentage units) compared with cows in RPM for PFTN ( -0.01 percentage units) and HSC ( -0.02 percentage units). Cows in RPM tended $(P=0.06)$ to have a greater increase in milk fat concentration for PFTN $(+0.02$ percentage units) and HSC (+0.12 percentage units) compared with cows in CON for PFTN (+0.01 percentage units) and HSC $(-0.10$ percentage units). An environment $\times$ diet interaction was present for milk fat concentration $(P=0.05)$ and milk casein concentration $(P=0.04)$. A tendency for an environment $\times$ diet interaction was present for milk protein concentration $(P=0.07)$. A day effect was present for DMI $(P<0.001$; Figure $1 \mathrm{~B})$, milk yield $(P<0.001$; Figure $1 \mathrm{C})$, FCM yield $(P=0.04)$, ECM yield $(P=0.04)$, milk fat yield $(P$ $=0.07)$, milk protein concentration $(P=0.006)$, milk protein yield $(P=0.001)$, milk casein concentration $(P$ $=0.001)$, milk casein yield $(P=0.002)$, milk casein as 


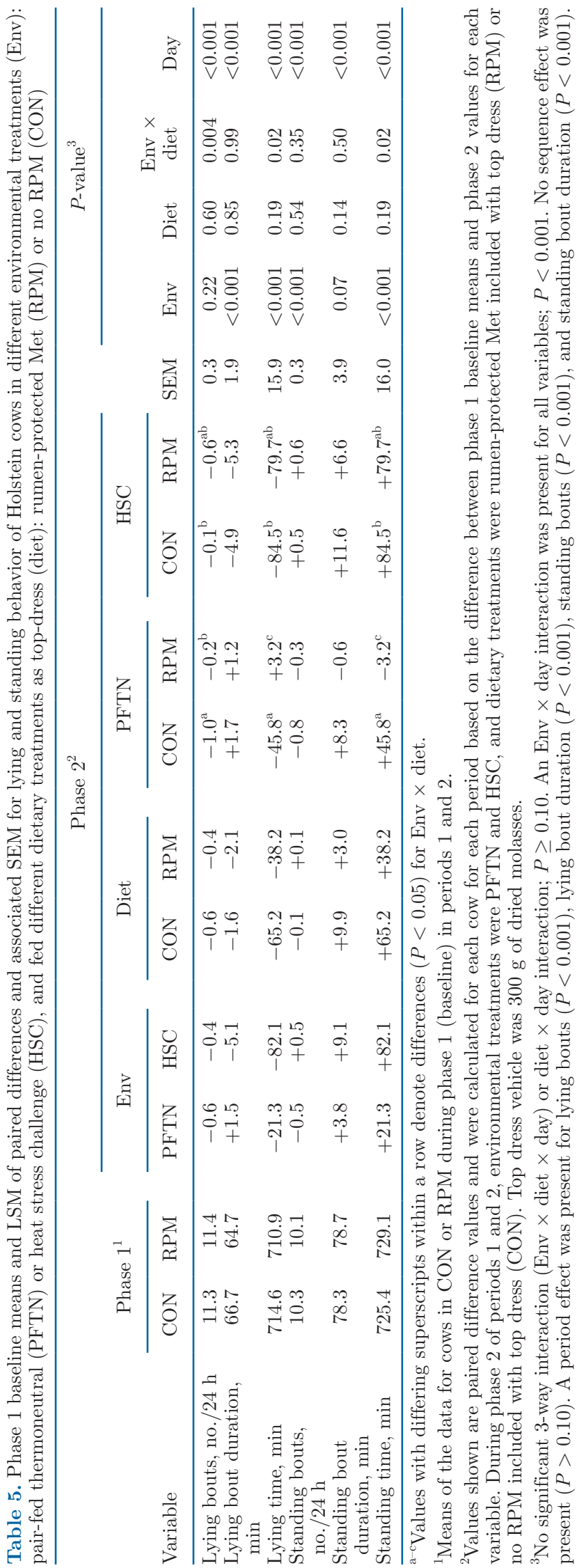

a proportion of total protein $(P=0.002)$, milk lactose concentration $(P=0.01)$, MUN $(P=0.06)$, FCM/DMI $(P=0.04)$, and ECM/DMI $(P=0.05)$. An environment $\times$ day interaction was present for $\operatorname{MUN}(P=$ 0.05; Figure 2).

\section{DISCUSSION}

The objectives of this study were to evaluate the effects of a commercially available RPM source (Smartamine M; Adisseo Inc., Antony, France) fed at 1.05 $\mathrm{g}$ of $\mathrm{RPM} / \mathrm{kg}$ of DMI on lactation performance and physiological responses of lactating, multiparous Holstein cows during a HSC. Our hypothesis was that cows receiving RPM would experience improved lactation performance responses during a HSC compared with cows that did not receive RPM during a HSC.

As anticipated, cows in HSC experienced marked signs of hyperthermia compared with those in PFTN during phase 2. Cows in HSC had a greater increase in vaginal, rectal, and skin temperatures, as well as a greater increase in respiration rate and heart rate, compared with cows in PFTN. These results are similar to those reported in previous reviews and experiments evaluating the effects of HS on dairy cows (Kadzere et al., 2002; Fabris et al., 2019). However, it is important to note that based on physiological measures such as rectal temperature and respiration rate, HS was less severe in the current study compared with previous reports utilizing an EHB model of HS. Al-Qaisi et al. (2019) reported a $1.2^{\circ} \mathrm{C}$ increase in rectal temperature and a 29 breaths/min increase in respiration rate for cows experiencing HS via EHB, compared with cows not in HS. The difference in physiological measurements between the current study and previous studies may be due to the differences in housing and ambient environment (tiestall and box-stall, respectively; $\mathrm{Al}$ Qaisi et al., 2019), as well as the time of year in which the studies were conducted. Additionally, cows in the current study were milked $3 \times$ per day and the EHB were turned off during milking in order bring cows to the milking parlor (approximately $1 \mathrm{~h}$ per milking and $3 \mathrm{~h}$ per day; approximately 0.5 to $1 \mathrm{~h}$ per milking and 1.5 to $3 \mathrm{~h}$ per day for blankets to return to pre-disconnection temperatures), whereas cows in the aforementioned experiment were milked $2 \times$ per day. However, as previously mentioned, cows in the current study showed physiological signs of hyperthermia similar to those experienced by cows in freestall facilities (Fabris et al., 2019). Therefore, hyperthermia was successfully achieved via EHB in the current study, and HSC severity mimicked HS conditions experienced in commercial settings. Another discussion point is that cows in HSC may have experienced signs of hyperthermia due to 
Pate et al.: HEAT STRESS AND RUMEN-PROTECTED METHIONINE

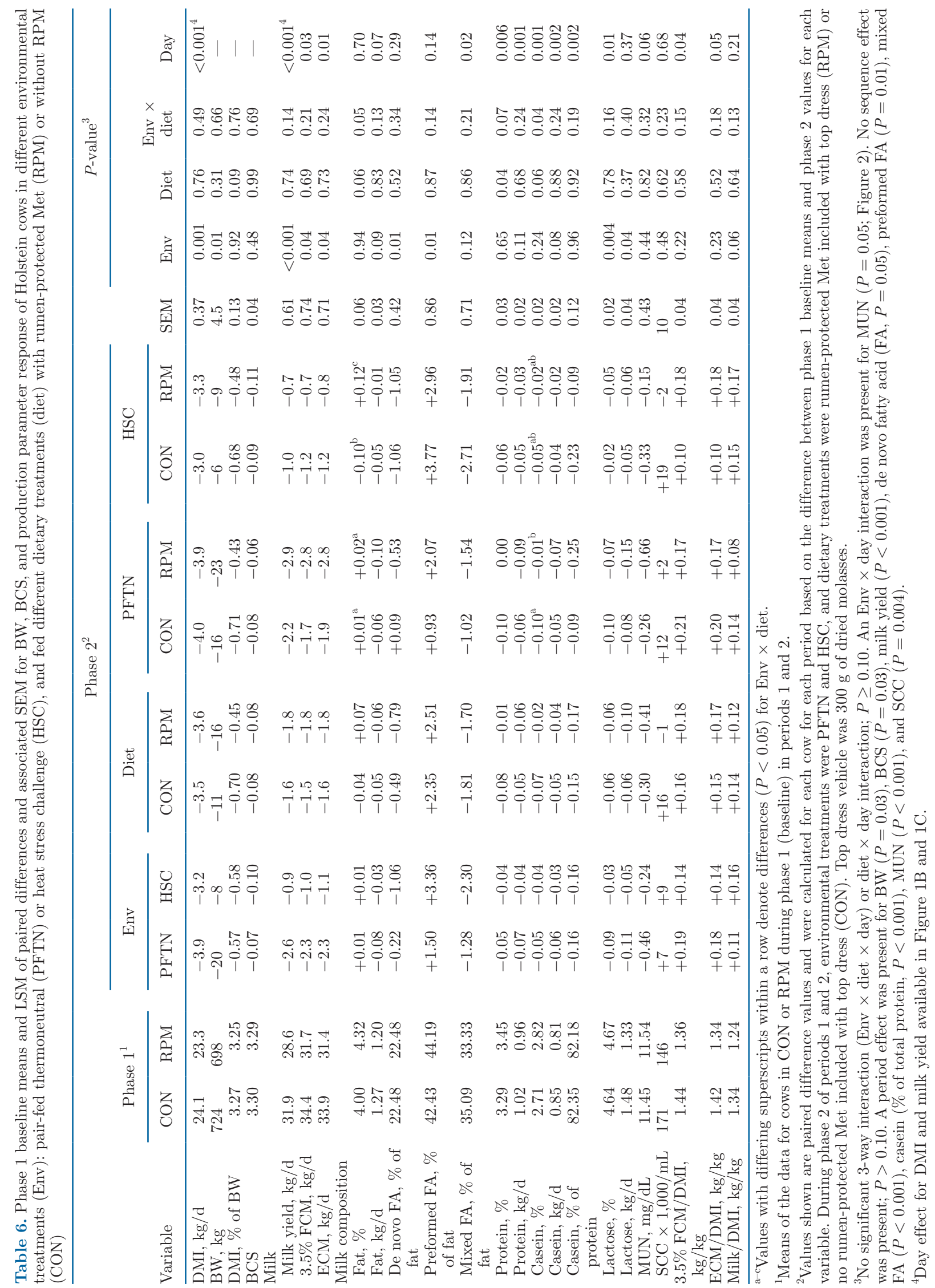




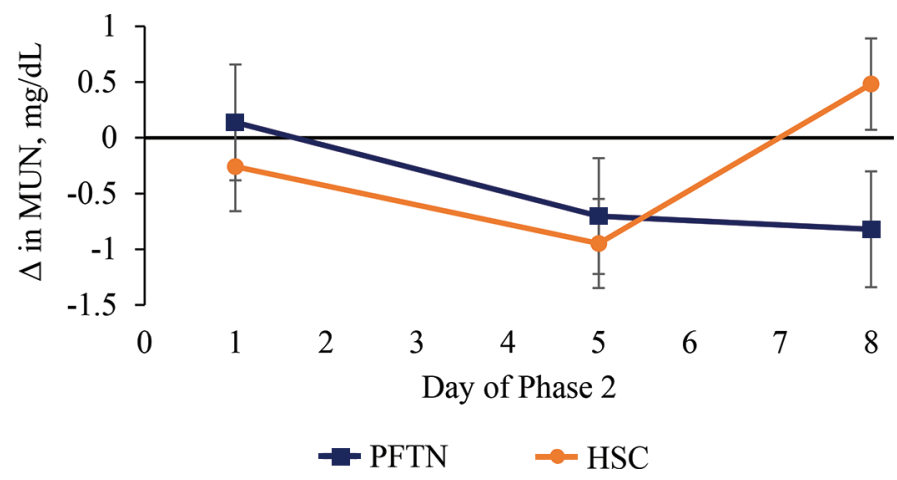

Figure 2. Least squares means of paired differences and associated SEM for MUN (mg/dL) for Holstein cows in different environmental treatments: pair-fed thermoneutral (PFTN, blue squares) or heat stress challenge (HSC, orange circles). Data were collected on d 1, 5, and 8 of phase 2. Environment $\times$ day: $P=0.05$. Paired differences values were calculated for each cow for each period based on the difference between phase 1 baseline means (black horizontal line) and phase 2 values for each variable.

reduced thermal transfer to the environment caused by the EHB. One mechanism for evaluating this response would be the measurement of skin temperature directly under the blanket as opposed to neck skin temperature. Although this measurement was not conducted in the current experiment, skin temperature under the EHB should be evaluated in studies henceforth. Furthermore, cows in RPM tended to have increased vaginal temperature compared with cows in CON for both PFTN and HSC. The biological relevance of these data must be carefully evaluated.

Increased ambient temperature and humidity have been shown to alter dairy cattle activity. Previous research reported increased standing behavior and decreased lying behavior when cows were subject to conditions of HS (THI >68; Cook et al., 2007; Allen et al., 2015; Nordlund et al., 2019). Similar results were reported in the current study, as cows in HSC had an increased number of standing bouts (no./24 h), standing bout duration ( $\mathrm{min}$ ), and total standing time (minutes), with a decrease in lying bout duration (min) and total lying time (min) compared with cows in PFTN. Increased standing time, and subsequently, decreased lying time, for cows in HSC is likely an attempt by cows to dissipate heat to the environment via radiation, evaporation, convection, conduction, or a combination of these (Kadzere et al., 2002). Additionally, cows in PF-C had increased total standing time, decreased lying bouts, and decreased total lying time during phase 2 compared cows in PF-M. To the authors' knowledge, minimal data are available on the relationship between restricted feed intake (i.e., pair-feeding), AA supplementation, and activity. The authors postulate that restricted intake during PFTN may have resulted in unbalanced AA profile and negative energy balance, resulting in increased standing time as an intuitive attempt by the cow to search for food (Sugden and Fuller, 1991; Schwab and Broderick, 2017). In the current study supplementation of RPM may have aided in maintaining energy balance via AA proportions in MP (NRC, 2001; Schwab and Broderick, 2017), leading to more efficient AA utilization and protein synthesis (Martinov et al., 2010; Zhou et al., 2016). This may have resulted in a decreased drive to search for food and subsequent decreased standing time. More research is needed regarding the effects of RPM feeding on cow activity during restricted feed intake, as well as on the physiological relevance of these data.

Historically, DMI has been considered the main cause of decreased production response in dairy cattle under HS conditions. However, work in pigs (Pearce et al., 2013) and dairy cows (Rhoads et al., 2009; Wheelock et al., 2010; Cowley et al., 2015; Gao et al., 2017) have sought to determine the specific effects of HS, beyond decreased DMI, by utilizing a pair-feeding model. In the current study, cows in PFTN had a greater decrease in DMI compared with cows in HSC ( -3.9 vs. -3.2 $\mathrm{kg} / \mathrm{d}$, respectively) during phase 2 . This $0.7 \mathrm{~kg} / \mathrm{d}$ difference in DMI between the PFTN and HSC groups is similar to previous trials utilizing a pair-feeding model. Rhoads et al. (2009) reported a $1.2 \mathrm{~kg} / \mathrm{d}$ difference in DMI for cows in PFTN compared with cows in HSC (15.6 and $16.8 \mathrm{~kg} / \mathrm{d}$, respectively), and Wheelock et al. (2010) reported a $1.1 \mathrm{~kg} / \mathrm{d}$ difference in DMI for cows in PFTN compared with those in HSC (13.0 and 14.1 $\mathrm{kg} / \mathrm{d}$, respectively). Furthermore, there was no difference between cows in HSC and PFTN regarding the reduction in DMI as a proportion of $\mathrm{BW}(-0.57$ and $-0.58 \%$, respectively). Assessing DMI as a percentage of BW may offer a more accurate indication of the comparison between DMI of groups of cows with dissimilar BW, as seen in the current experiment. Additionally, these data support the current pair-feeding experimental design, as cows in PFTN were intentionally fed equal percentages of decreased DMI as cows in HSC.

Although DMI data for the current experiment are similar to previous HS experiments utilizing a pairfeeding model, milk yield data are dissimilar. In the present study, cows in PFTN had a greater decrease in milk yield compared with cows in HSC $(-8.8$ and $-3.0 \%$, respectively) during phase 2 . In contrast, HS cows have previously been shown to have a greater decrease in milk yield compared with those in PFTN. Rhoads et al. (2009) reported a 40 and $21 \%$ reduction in milk yield for cows in HS and PFTN, respectively, whereas Wheelock et al. (2010) reported a 28 and $14 \%$ reduction in milk yield for HS and PFTN, respectively. Although HS duration of the aforementioned experi- 
ments ( 7 and $9 \mathrm{~d}$ ) was similar to the current study (9d), it is important to note that EHB-induced HS for cows in tiestall facilities, as used in the current experiment, may elicit different milk yield results than HS induced via temperature-controlled chambers (Rhoads et al., 2009; Wheelock et al., 2010; Cowley et al., 2015) or via EHB in box-stall facilities (Al-Qaisi et al., 2019). The fact that cows in the current trial were removed from electrical heat source $3 \times$ per day for milking, whereas heat application was constant for aforementioned trials, is also important to note. These discrepancies in HS induction technique, housing facility, and management practices may explain the differing milk yield responses between the current experiment and previous experiments. Furthermore, in the current trial, it took a few days before the effects of HS to alter both vaginal temperature and milk yield for cows in HSC during phase 2 (Figures $1 \mathrm{~A}$ and $1 \mathrm{C}$, respectively), whereas the effects on DMI were relatively immediate for cows in HSC and PFTN (Figure 1B). These data, along with the alterations in milk fat composition (Table 1) and MUN (Figure 2) as discussed hereafter, may suggest metabolic changes to cows in HSC that would support milk yield during the first few days of HSC. Concurrently, the immediate decrease in DMI via feed restriction may have caused cows in PFTN to undergo greater initial stress than cows in HSC with ad libitum access to feed, thus resulting in a greater overall decrease in milk yield during phase 2. Further research should be conducted comparing the severity of stress caused by HS or restricted feed intake, and their effects on lactation performance.

An increase in milk fat concentration for cows in HSCM compared with HSC-C, and a tendency for increased milk fat concentration for cows in RPM compared with cows in CON was reported in the current study. These data are corroborated by previous research, as HS has been reported to decrease milk fat concentration in dairy cattle (Huber, 1996; Bouraoui et al., 2002; Kadzere et al., 2002). Additionally, Osorio et al. (2013) and Batistel et al. (2017) reported increased milk fat percentage and milk fat yield for cows receiving RPM compared with cows without RPM during stress conditions (i.e., periparturient period). Also, Chen et al. (2011) reported increased milk fat concentration when mid-lactation cows were supplemented with Met. The biological mechanism behind increased milk fat concentration for cows receiving Met supplementation during HS is not completely understood. One hypothesis is that Met induces efficient packaging of liver TAG into VLDL due to increased apolipoprotein B-100 synthesis, thus leading to increased FA reaching the mammary gland for milk fat inclusion (Bauchart et al., 1998; Osorio et al., 2013). However, the literature regarding Met role in hepatic VLDL packaging is inconsistent (Chandler and White, 2017). Another mechanism could be that balanced feeding of indispensable AA (i.e., Met) may aid in mammary gland de novo FA synthesis due to increased mRNA expression of lipogenic enzymes, thus leading to increased milk fat concentration and milk fat yield (Li et al., 2016; Batistel et al., 2017). If these hypotheses were to be upheld, a shift in milk FA composition would be expected for cows receiving RPM. However, in the current study no difference was observed in de novo FA concentration (as a percentage of total milk fat) or preformed FA concentration (as a percentage of total milk fat) between cows in RPM and CON. Therefore, more research is needed to elucidate the relationship between RPM feeding and milk fat concentration during HS. Furthermore, cows in HSC had a greater decrease in milk de novo FA concentration (as a percentage of total fat; -1.50 percentage units) and a greater increase in milk preformed FA concentration $(+3.36$ percentage units) compared with cows in PFTN $(-0.22$ and +1.50 percentage units, respectively) during phase 2. A decrease in de novo FA concentration has been attributed to decreased milk fat synthesis from rumen-derived precursors in the mammary gland (i.e., acetate; Lynch et al., 1992; Craninx et al., 2008; Barbano et al., 2019). Kelley et al. (1967) and Attebery and Johnson (1969) reported altered rumen function and decreased VFA production in cows subject to HS conditions. Previous research has also suggested that, during HS, nutrient partitioning is diverted away from the mammary gland due to tissue-specific hormonal sensitivity alterations (Baumgard and Rhoads, 2013; Baumgard et al., 2015). Additionally, a shift in blood flow away from the mammary gland toward the skin surface in heat-stressed animals has been reported, which could result in decreased FA precursors reaching the mammary gland (Hales, 1973; Lough et al., 1990). Taken together, these data support the shift in de novo FA and preformed FA concentration in milk during HSC, as seen in the current study.

In the current study, no difference was observed in milk protein concentration decrease or milk casein concentration decrease between cows in HSC and PFTN. Similar results were reported by Cowley et al. (2015) in regard to milk protein concentration between cows in HS and PFTN conditions. However, in that study, a decrease in milk casein concentration for cows in HS was reported (Cowley et al., 2015). Additionally, Gao et al. (2017) reported a decrease in milk protein concentration, and Al-Qaisi et al. (2019) reported a tendency for decreased milk protein concentration, for cows in HS compared with those in PFTN. Conflicting results between the current study and previous studies with regard to milk protein and casein concentrations may 
be due to aforementioned experimental differences in HS induction technique and severity, housing facility, and management practices.

It is important to note the environment $x$ day interaction for MUN difference during phase 2 (Figure 2). By the end of phase 2, cows in HSC had increased MUN $(+0.5 \mathrm{mg} / \mathrm{dL})$, whereas cows in PFTN had decreased MUN (-1.0 mg/dL). Increased MUN has been previously reported for cows in HS conditions (Wheelock et al., 2010; Cowley et al., 2015; Al-Qaisi et al., 2019) and has been attributed to increased skeletal muscle catabolism to supply AA to the liver for gluconeogenesis, as well as acute phase protein and heat shock protein synthesis (Collier et al., 2008; Baumgard and Rhoads, 2013; Ríus, 2019). Similar to previous reports (Osorio et al., 2013; Zhou et al., 2016), RPM feeding supported milk protein concentration, as cows in CON had a greater decrease in milk protein concentration and tended to have greater decrease in milk casein concentration compared with cows in RPM. Moreover, cows in PF-C had a greater decrease in milk casein concentration than cows in PF-M. Greater milk protein concentration and milk casein concentration when cows were supplemented with RPM is likely due to sufficient Met as a proportion of MP (NRC, 2001; Schwab and Broderick, 2017), as well as the direct effect of Met supplementation on protein synthesis pathways (i.e., the mTOR pathway) in mammary epithelial tissue (Nan et al., 2014; Li et al., 2016). The exact mechanism by which HS affects protein synthesis, as well as the mechanism by which indispensable AA supplementation during HS alters protein synthesis, warrants further study.

The effect of period on multiple physiological, activity, and performance variables is reported in Tables 4 , 5 , and 6. It is important to note that in the current study a washout period, in which no RPM feeding and no HSC or pair-feeding occurred, was implemented to reduce the effect of carryover effects of nutritional or environmental treatments. Therefore, the authors believe that the period effects are not a result of experimental treatments. Furthermore, effects of period are likely attributed to factors such as stage of lactation or ambient environment due to the time of year in which the periods occurred.

Cows in PFTN had a greater decrease in milk lactose concentration and milk lactose yield than cows in HSC. Rhoads et al. (2009) and Shwartz et al. (2009) both reported similar decreases in milk lactose concentration for cows in both HS and PFTN conditions. The authors of those studies postulated that the decrease in lactose concentration was likely due to the decrease in DMI experienced by both groups of cows. Data from our trial are in agreement with these hypotheses, as the lac- tose concentration decrease coincided with a decrease in DMI for cows in both HSC and PFTN.

\section{CONCLUSIONS}

Cows in HSC exhibited physiological signs of hyperthermia similar to those experienced by cows in a commercial dairy setting, as vaginal, skin, and rectal temperature increased, along with respiration rate and heart rate. Feeding RPM did not alter physiological parameters during HSC. Additionally, HSC caused alterations in cow behavior, such as increased standing time and decreased lying time. Cows in PFTN conditions had a greater decrease in DMI and milk yield than cows in HSC. Feeding RPM improved milk composition during HSC, primarily as a result of higher milk fat and milk protein concentration. Additionally, DMI, milk yield, and feed efficiency were not affected by RPM during HSC. Still to be determined are the effects of RPM feeding to dairy cows during HS on blood parameters, immunological function, and liver and mammary gland function, as well as the duration and severity of HS on lactation performance and overall health.

\section{ACKNOWLEDGMENTS}

This project was partially supported by Adisseo (Alpharetta, GA) and by the USDA National Institute of Food and Agriculture (Washington, DC; NC-2042). We thank Ajinomoto Heartland Inc. (Chicago, IL) for the donation of Ajipro-L Generation 3, Dairy Nutrition Plus (Ralston, IA) for the donation of Soyplus, and Perdue AgriBusiness (Salisbury, MD) for the donation of ProVAAl AADvantage during the course of the experiment. Sincere appreciation is expressed to the Dairy Focus Team at the University of Illinois, along with the University of Illinois Dairy Research Unit staff for assisting with data collection and cow health. D. Luchini was involved in the experimental design and discussion of the present manuscript. The authors have not stated any conflicts of interest.

\section{REFERENCES}

Al-Qaisi, M., E. A. Horst, S. K. Kvidera, E. J. Mayorga, L. L. Timms, and L. H. Baumgard. 2019. Technical note: Developing a heat stress model in dairy cows using an electric heat blanket. J. Dairy Sci. 102:684-689. https://doi.org/10.3168/jds.2018-15128.

Allen, J. D., L. W. Hall, R. J. Collier, and J. F. Smith. 2015. Effect of core body temperature, time of day, and climate conditions on behavioral patterns of lactating dairy cows experiencing mild to moderate heat stress. J. Dairy Sci. 98:118-127. https://doi.org/10 .3168/jds.2013-7704.

AOAC International. 1995a. Official method 934.01. Moisture in animal feed. Pages 23-26 in Official Methods of Analysis. 16th ed. Vol. 2. AOAC International, Arlington, VA. 
AOAC International. 1995b. Official method 972.16. Fat, lactose, protein, and solids in milk. Mid-infrared spectroscopic method. Pages 2-5 in Official Methods of Analysis. 16th ed. Vol. 2. AOAC International, Arlington, VA.

Attebery, J. T., and H. D. Johnson. 1969. Effects of environmental temperature, controlled feeding and fasting on rumen motility. J. Anim. Sci. 29:734-737. https://doi.org/10.2527/jas1969.295734x.

Barbano, D. M., C. Melilli, H. Dann, and R. Grant. 2019. The use of milk fatty acids as an indication of energy balance in dairy cows. Pages 52-70 in Proc. Ruminant Nutr. Symp. University of Florida, Gainesville.

Batistel, F., J. M. Arroyo, A. Bellingeri, L. Wang, B. Saremi, C. Parys, E. Trevisi, F. C. Cardoso, and J. J. Loor. 2017. Ethyl-cellulose rumen-protected methionine enhances performance during the periparturient period and early lactation in Holstein dairy cows. J. Dairy Sci. 100:7455-7467. https://doi.org/10.3168/jds.2017-12689.

Bauchart, D., D. Durand, D. Gruffat, and Y. Chilliard. 1998. Mechanism of liver steatosis in early lactation cows: Effects of hepatoprotector agents. Pages 49-56 in Proc. Cornell Nutr. Conf. Feed Manuf. Cornell University, Ithaca, NY.

Baumgard, L. H., A. Keating, J. W. Ross, and R. P. Rhoads. 2015. Effects of heat stress on the immune system, metabolism and nutrient partitioning: Implications on reproductive success. Rev. Bras. Reprod. Anim., Belo Horizonte. 39:173-183.

Baumgard, L. H., and R. P. Rhoads Jr.. 2013. Effects of heat stress on postabsorptive metabolism and energetics. Annu. Rev. Anim. Biosci. 1:311-337. https://doi.org/10.1146/annurev-animal-031412 -103644 .

Baumgard, L. H., J. B. Wheelock, S. R. Sanders, C. E. Moore, H. B. Green, M. R. Waldron, and R. P. Rhoads. 2011. Postabsorptive carbohydrate adaptations to heat stress and monensin supplementation in lactating Holstein cows. J. Dairy Sci. 94:5620-5633. https://doi.org/10.3168/jds.2011-4462.

Beede, D. K., and R. J. Collier. 1986. Potential nutritional strategies for intensively managed cattle during thermal stress. J. Anim. Sci. 62:543-554. https://doi.org/10.2527/jas1986.622543x.

Berman, A. 2003. Effects of body surface area estimates on predicted energy requirements and heat stress. J. Dairy Sci. 86:3605-3610. https://doi.org/10.3168/jds.S0022-0302(03)73966-6.

Bernabucci, U., and L. Calamari. 1998. Effects of heat stress on bovine milk yield and composition. Zootec. Nutr. Anim. 24:247-257.

Bernabucci, U., N. Lacetera, L. H. Baumgard, R. P. Rhoads, B. Ronchi, and A. Nardone. 2010. Metabolic and hormonal acclimation to heat stress in domesticated ruminants. Animal 4:1167-1183. https: //doi.org/10.1017/S175173111000090X.

Bouraoui, R., M. Lahmar, A. Majdoub, M. Djemali, and R. Belyea. 2002. The relationship of temperature-humidity index with milk production of dairy cows in a Mediterranean climate. Anim. Res. 51:479-491. https://doi.org/10.1051/animres:2002036.

Buffington, D. E., A. Collazo-Arocho, G. H. Canton, D. Pitt, W. W. Thatcher, and R. J. Collier. 1981. Black globe-humidity index (BGHI) as comfort equation for dairy cows. Trans. ASAE 24:7110714. https://doi.org/10.13031/2013.34325.

Chandler, T. L., and H. M. White. 2017. Choline and methionine differentially alter methyl carbon metabolism in bovine neonatal hepatocytes. PLoS One 12:e0171080. https://doi.org/10.1371/ journal.pone. 0171080 .

Chen, Z. H., G. A. Broderick, N. D. Luchini, B. K. Sloan, and E. Devillard. 2011. Effect of feeding different sources of rumen-protected methionine on milk production and N-utilization in lactating dairy cows. J. Dairy Sci. 94:1978-1988. https://doi.org/10.3168/jds.2010 -3578 .

Collier, R. J., J. L. Collier, R. P. Rhoads, and L. H. Baumgard. 2008. Invited Review: Genes involved in the bovine heat stress response. J. Dairy Sci. 91:445-454. https://doi.org/10.3168/jds.2007-0540.

Collier, R. J., B. J. Renquist, and Y. Xiao. 2017. A 100-Year Review: Stress physiology including heat stress. J. Dairy Sci. 100:1036710380. https://doi.org/10.3168/jds.2017-13676.

Cook, N. B., R. L. Mentink, T. B. Bennett, and K. Burgi. 2007. The effect of heat stress and lameness on time budgets of lactating dairy cows. J. Dairy Sci. 90:1674-1682. https://doi.org/10.3168/ jds.2006-634.

Cowley, F. C., D. G. Barber, A. V. Houlihan, and D. P. Poppi. 2015. Immediate and residual effects of heat stress and restricted intake on milk protein and casein composition and energy metabolism. J. Dairy Sci. 98:2356-2368. https://doi.org/10.3168/jds.2014-8442.

Craninx, M., A. Steen, H. Van Laar, T. Van Nespen, J. Martín-Tereso, B. de Baets, and V. Fievez. 2008. Effect of lactation stage on the odd- and branched-chain milk fatty acids of dairy cattle under grazing and indoor conditions. J. Dairy Sci. 91:2662-2677. https:/ /doi.org/10.3168/jds.2007-0656.

Fabris, T. F., J. Laporta, A. L. Skibiel, F. N. Corra, B. D. Senn, S. E. Wohlgemuth, and G. E. Dahl. 2019. Effect of heat stress during early, late, and entire dry period on dairy cattle. J. Dairy Sci. 102:5647-5656. https://doi.org/10.3168/jds.2018-15721.

Ferguson, J. D., D. T. Galligan, and N. Thomsen. 1994. Principal descriptors of body condition score in Holstein cows. J. Dairy Sci. 77:2695-2703. https://doi.org/10.3168/jds.S0022-0302(94)77212 $-\mathrm{X}$.

Gao, S. T., J. Guo, S. Y. Quan, X. M. Nan, M. V. S. Fernandez, L. H. Baumgard, and D. P. Bu. 2017. The effects of heat stress on protein metabolism in lactating Holstein cows. J. Dairy Sci. 100:5040-5049. https://doi.org/10.3168/jds.2016-11913.

Hales, J. R. S. 1973. Effects of exposure to hot environments on the regional distribution of blood flow on cardiorespiratory function in sheep. Pflugers Arch. 344:133-148. https://doi.org/10.1007/ BF00586547.

Huber, J. T. 1996. Amelioration of heat stress in dairy cattle. Pages 211-243 in Progress in Dairy Science. C. J. C. Philips, ed. CAB International, Wallingford, UK.

Kadzere, C. T., M. R. Murphy, N. Silanikove, and E. Maltz. 2002. Heat stress in lactating dairy cows: A review. Livest. Prod. Sci. 77:59-91. https://doi.org/10.1016/S0301-6226(01)00330-X.

Kelley, R. O., F. A. Martz, and H. D. Johnson. 1967. Effect of environmental temperature on ruminal volatile fatty acid levels with controlled feed intake. J. Dairy Sci. 50:531-533. https://doi.org/10 .3168/jds.S0022-0302(67)87460-5.

Kononoff, P. J., A. Heinrichs, and D. Buckmaster. 2003. Modification of the Penn State forage and total mixed ration particle separator and the effects of moisture content on its measurements. J. Dairy Sci. 86:1858-1863. https://doi.org/10.3168/jds.S0022 -0302(03)73773-4.

Krause, K. M., D. Dhuyvetter, and G. Oetzel. 2009. Effect of a lowmoisture buffer block on ruminal $\mathrm{pH}$ in lactating dairy cattle induced with subacute ruminal acidosis. J. Dairy Sci. 92:352-364. https://doi.org/10.3168/jds.2007-0959.

Ledgerwood, D. N., C. Winckler, and C. B. Tucker. 2010. Evaluation of data loggers, sampling intervals, and editing techniques for measuring the lying behavior of dairy cattle. J. Dairy Sci. 93:51295139. https://doi.org/10.3168/jds.2009-2945.

Lemerle, C., and M. E. Goddard. 1986. Assessment of heat stress in dairy cattle in Papua New Guinea. Trop. Anim. Health Prod. 18:232-242. https://doi.org/10.1007/BF02359540.

Li, S., A. Hosseini, M. Danes, C. Jacometo, J. Liu, and J. J. Loor. 2016. Essential amino acid ratios and mTOR affect lipogenic gene networks and miRNA expression in bovine mammary epithelial cells. J. Anim. Sci. Biotechnol. 7:44. https://doi.org/10.1186/ s40104-016-0104-x.

Littell, R. C. 2002. Analysis of unbalanced mixed model data: A case study comparison of ANOVA versus REML/GLS. J. Agric. Biol. Environ. Stat. 7:472-490. https://doi.org/10.1198/108571102816.

Lough, D. S., D. L. Beede, and C. J. Wilcox. 1990. Effects of feed intake and thermal stress on mammary blood flow and other physiological measurements in lactating dairy cows. J. Dairy Sci. 73:325-332. https://doi.org/10.3168/jds.S0022-0302(90)78677-8.

Lynch, J. M., D. M. Barbano, D. E. Bauman, G. F. Hartnell, and M. A. Nemeth. 1992. Effect of a prolonged-release formulation of n-methionyl bovine somatotropin (Sometribove ${ }^{\circledR}$ ) on milk fat. J. Dairy Sci. 75:1775-1809. 
Martinov, M. V., V. M. Vitvitsky, R. Banerjee, and F. I. Ataullakhanov. 2010. The logic of the hepatic methionine metabolic cycle. Biochim. Biophys. Acta 1804:89-96. https://doi.org/10.1016/j .bbapap.2009.10.004.

Maust, L. E., W. G. Pond, and M. L. Scott. 1972. Energy value of a cassava-rice bran diet with and without supplemental zinc for growing pigs. J. Anim. Sci. 35:953-957. https://doi.org/10.2527/ jas1972.355953x.

Nan, X., D. Bu, X. Li, J. Wang, H. Wei, H. Hu, L. Zhou, and J. J. Loor. 2014. Ratio of lysine to methionine alters expression of genes involved in milk protein transcription and translation and mTOR phosphorylation in bovine mammary cells. Physiol. Genomics 46:268-275. https://doi.org/10.1152/physiolgenomics.00119.2013.

Nardone, A., N. Lacetera, U. Bernabucci, and B. Ronchi. 1997. Composition of colostrum from dairy heifers exposed to high air temperatures during late pregnancy and the early postpartum period. J. Dairy Sci. 80:838-844. https://doi.org/10.3168/jds.S0022 -0302(97)76005-3.

Nordlund, K. V., P. Strassburg, T. B. Bennett, G. R. Oetzel, and N. B. Cook. 2019. Thermodynamics of standing and lying behavior in lactating dairy cows in freestall and parlor holding pens during conditions of heat stress. J. Dairy Sci. 102:6495-6507. https://doi .org/10.3168/jds.2018-15891.

NRC. 2001. Nutrient Requirements of Dairy Cattle. 7th rev. ed. Natl. Acad. Press, Washington, DC.

Osorio, J. S., P. Ji, J. K. Drackley, D. Luchini, and J. J. Loor. 2013. Supplemental Smartamine $\mathrm{M}^{\circledR}$ or MetaSmart ${ }^{\circledR}$ during the transition period benefits postpartal cow performance and blood neutrophil function. J. Dairy Sci. 96:6248-6263. https://doi.org/10 $.3168 / \mathrm{jds} .2012-5790$.

Pate, R. T., and F. C. Cardoso. 2018. Injectable trace minerals (selenium, copper, zinc, and manganese) alleviates inflammation and oxidative stress during an aflatoxin challenge in lactating multiparous Holstein cows. J. Dairy Sci. 101:8532-8543. https://doi.org/ $10.3168 /$ jds.2018-14447.

Pearce, S. C., N. K. Gabler, J. W. Ross, J. Escobar, J. F. Patience, R. P. Rhoads, and L. H. Baumgard. 2013. The effects of heat stress and plane of nutrition on metabolism in growing pigs. J. Anim. Sci. 91:2108-2118. https://doi.org/10.2527/jas.2012-5738.

Rhoads, M. L., R. P. Rhoads, M. J. VanBaale, R. J. Collier, S. R. Sanders, W. J. Weber, B. A. Crooker, and L. H. Baumgard. 2009. Effects of heat stress and plane of nutrition on lactating Holstein cows: I. Production, metabolism, and aspects of circulating somatotropin. J. Dairy Sci. 92:1986-1997. https://doi.org/10.3168/ jds.2008-1641.

Ríus, A. G. 2019. Invited Review: Adaptations of protein and amino acid metabolism to heat stress in dairy cows and other livestock species. Appl. Anim. Sci. 35:39-48. https://doi.org/10.15232/aas $.2018-01805$.

Ross, D. A., M. Gutierrez-Botero, and M. E. Van Amburgh. 2013. Development of an in vitro intestinal digestibility assay for ruminant feeds. Pages 190-202 in Proc. Cornell Nutr. Conf. Feed Manuf. Cornell Univ., Ithaca, NY.
Schwab, C. 2012. The principles of balancing diets for amino acids and their impact on N utilization efficiency. Pages 1-15 in Proc. Ruminant Nutr. Symp. University of Florida, Gainesville.

Schwab, C., N. Whitehouse, D. Luchini, and B. Sloan. 2009. Reevaluation of the breakpoint estimates for the NRC (2001) required concentrations of lysine and methionine in metabolizable protein for maximal content and yield of milk protein. J. Dairy Sci. 92(Suppl. 1):103. (Abstr.)

Schwab, C. G., and G. A. Broderick. 2017. A 100-Year Review: Protein and amino acid nutrition in dairy cows. J. Dairy Sci. 100:1009410112. https://doi.org/10.3168/jds.2017-13320.

Shwartz, G., M. L. Rhoads, M. J. VanBaale, R. P. Rhoads, and L. H. Baumgard. 2009. Effects of a supplemental yeast culture on heatstressed lactating Holstein cows. J. Dairy Sci. 92:935-942. https:/ /doi.org/10.3168/jds.2008-1496.

Silanikove, N., E. Maltz, D. Shinder, E. Bogin, T. Bastholm, N. J. Christensen, and P. Norggarrd. 1998. Metabolic and productive responses of dairy cows to increased ion supplementation at early lactation in warm weather. J. Dairy Res. 65:529-543. https://doi .org/10.1017/S0022029998003185.

St-Pierre, N. R., B. Cobanov, and G. Schnitkey. 2003. Economic losses from heat stress by US livestock industries. J. Dairy Sci. 86:E52E77. https://doi.org/10.3168/jds.S0022-0302(03)74040-5.

Sugden, P. H., and S. J. Fuller. 1991. Regulation of protein turnover in skeletal and cardiac muscle. Biochem. J. 273:21-37. https://doi .org/10.1042/bj2730021.

Van Amburgh, M. E., T. R. Overton, L. E. Chase, D. A. Ross and E. B. Recktenwald. 2009. The Cornell net carbohydrate and protein system: Current and future approaches for balancing of amino acids. Pages 28-37 in Cornell Nutr. Conf. Feed Manuf. Cornell Univ. Ithaca, NY.

West, J. W. 1999. Nutritional strategies for managing the heatstressed dairy cow. J. Anim. Sci. 77(Suppl_2):21-35. https://doi .org/10.2527/1997.77suppl_221x.

Wheelock, J. B., R. P. Rhoads, M. J. VanBaale, S. R. Sanders, and L. H. Baumgard. 2010. Effects of heat stress on energetic metabolism in lactating Holstein cows. J. Dairy Sci. 93:644-655. https://doi .org/10.3168/jds.2009-2295.

Wojciechowski, K. L., and D. M. Barbano. 2016. Prediction of fatty acid chain length and unsaturation of milk fat by mid-infrared milk analysis. J. Dairy Sci. 99:8561-8570. https://doi.org/10 $.3168 /$ jds.2016-11248.

Zhou, Z., M. Vailati-Riboni, E. Trevisi, J. K. Drackley, D. N. Luchini, and J. J. Loor. 2016. Better postpartal performance in dairy cows supplemented with rumen-protected methionine compared with choline during the peripartal period. J. Dairy Sci. 99:8716-8732. https://doi.org/10.3168/jds.2015-10525.

\section{ORCIDS}

R. T. Pate (1) https://orcid.org/0000-0001-6284-635X

F. C. Cardoso $\odot$ https://orcid.org/0000-0003-1025-3231 